\title{
Yahwistic incongruency and enigma: A challenge to relinquish violence?
}

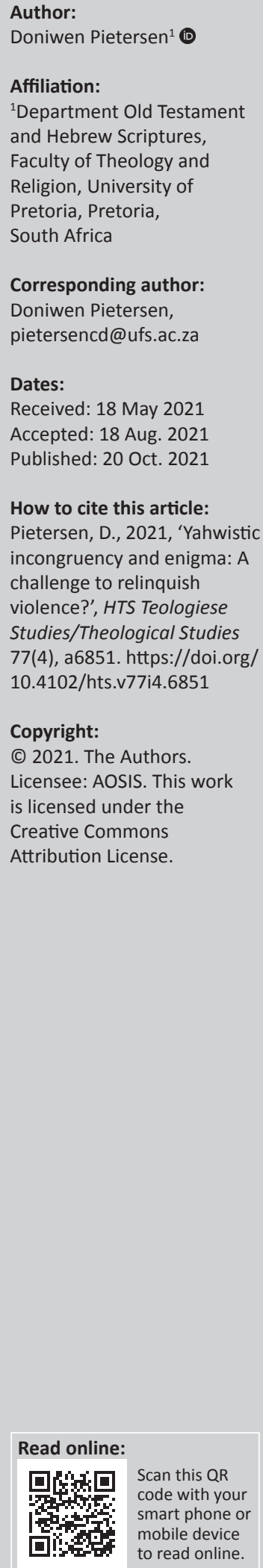

This article deals with the incongruency and enigma of violence on the part of Yahweh, in order to locate action or inaction against violence on a human level. The debate whether people should be actively involved in serving their countries in the military, if political leaders can wage war and take up arms against a corrupt, grossly oppressive and unjust regime, and if people should vote for and endorse parties with such policies, is contested. Furthermore, questions such as whether people can fight back when they are attacked on the street, whether they can own firearms and use them in self-defence when their families are under siege, and if they can physically harm a person who is in the process of sexually abusing their spouse, are indeed pertinent yet difficult questions to answer, especially in light of verses that say 'Blessed are the meek... blessed are the merciful... blessed are the peacemakers... blessed are those who are persecuted...' (Mt 5:3-10). The questions are foregrounded on the notion that appropriates the Christian use of violence to correct a wrong. For the purpose of this study, a historical and literary analysis was employed.

Contribution: This article contributes to the theological discourse within the Old Testament, ethical studies, New Testament studies as well as practical theology as it explores the intersections between the theological theme of violence by means of historical-critical and inter-textual reading methods.

Keywords: violence; Old Testament; renounce; ethics; incongruency and enigma.

\section{Introduction ${ }^{1}$}

In pursuit of knowing whether Christians should renounce violence or not, the title of this article presupposes that Christians ought to live in conformity to the prescription of the Bible. The United Nations (UN) defines violence more broadly as:

$[A] n y$ act that results in, or is likely to result in, physical, sexual, or mental harm or suffering to women, including threats of such acts, coercion or arbitrary deprivation of liberty, whether occurring in public or in private life. (World Health Organization 2021:1)

The UN definition and the biblical definition intersect. Both of these definitions will be used to determine whether violence is justified in any way from both a deity and human level. This is indeed a complex task that does not have a straightforward answer, and the purview of this article does not allow the chasing down of all possible cases studies. It is merely to give a biblically reasoned answer to the question. The solution this article will advance is: Christians should renounce violence and look forward to their vindication in the Second Coming (Huber 2011:5). This will be achieved by surveying the discussion of the historical-literary sources in order to highlight the incongruency and enigma against violence that may be advantageous or disadvantageous for those who follow Yahweh (Pietersen 2021:35-36).

\section{Methodology}

The method used in this article is historical-critical analysis. The article will interact with different biblical commentaries and sources that highlight this approach such as Collins work on The Bible after Babel: Historical Criticism in a Postmodern Age. The advantage of using this method is that historical criticism as a form of modern science helps to form a 'hypotheses which are either confirmed or disconfirmed by evidence' -in biblical sources. The theme of Yahweh's congruency on the issue of violence describes in this article a discussion between scholars which gradually approximates closer and closer to the truth of violence in biblical-historical texts. The conclusion 1.This article is the dissemination of a PhD entitled 'Disempowerment of and Violence against Women: Old Testament Perspectives,'
under the supervision of Prof. D.J Human, Department of Old Testament and Hebrew Scriptures, Faculty of Theology and Religion, University of Pretoria. 
in this article will uncover through plausible exegesis of the text's 'valid meaning' for a difficult topic (Collins 2005:17).

In this reading of Yahweh's incongruency and enigma on violence including the abstinence of violence from a human level, this work will also engage selected biblical texts on an intertextual level. Not only will this research interpret texts that deals with incongruency and enigma of violence within a social-political-economic-historical context (Pietersen 2021:45), but it will also interact and relate critically with what stance the Christian believer ought to take.

\section{Yahweh's view of violence}

In the Old Testament, we encounter bloodshed upon bloodshed. Murder dates back to the second generation of humankind when Cain killed his brother Abel (Gn 4: 8). Now at this point, it is important to recognise that God hated what Cain did and punished him (Gn 4:13). Having been grieved by man's wickedness at large, he wiped humankind off the face of the Earth with a flood (Gn 6). The Scripture specifically reads, 'the earth was corrupt in God's sight and was full of violence' (Gn 6:11). God with his own mouth said, 'I am going to put an end to all people, for the earth is filled with violence because of them' (Gn 6:13).

Of all the things that humankind could have been indicted for to warrant God's judgement on them by the flood, God singles out violence! We can at least thus, clearly adduce God's absolute disdain for violence from the above.

The flood however, could not put an end to the corruption of humankind, nor their propensity for violence. It was after the rapists, in the reputedly wicked Sodom and Gomorrah, 'struck the men who were at the door' (Gn 19:11), that the Lord 'rained down burning sulfur on Sodom and Gomorrah' (Gn 19:24) in judgement. Again, it was violence that was the apparent final nail in the Sodom and Gomorrahian coffin. Chapter 14 of Genesis records wars that broke out among the kingdoms of the Earth. Even Abram assembled an army to attack Lot's captors, yet out of all the peoples of the Earth, the Lord chose to confer blessing upon Abram and His descendants: to be their God and they his people (Gn 17:3-7) (Horsley 2003:77). Shockingly still, it was one of their own brothers that the blessed descendants of Abraham sort to kill: 'Come now, Let's kill him...' (Gn 37:20). Now although his brothers didn't go through with the murder and only sold him to the Ishmaelites, Joseph makes a profound statement to his brothers that is the key to understanding the Godordained attacks by Israel on nations inhabiting the promised land that follow Genesis and the Exodus: 'you intended to harm me, but God intended it for good to accomplish what is now being done, the saving of many lives' (Gn 50:20).

\section{The possibility of Yahweh using 'judicial violence'}

In the above verse we see God's superintendence over actions he does not prescribe. So although he works out his good purposes through Joseph's brothers' actions, he does not condone them. So far then, we have seen God's vehement disapproval of violence and at the same time using violence. For example, God's judgements by the flood and the rain of burning sulphur are quite violent themselves. The same can be said of God's judgement of the Egyptians by plagues and finally the Red Sea drowning of Pharaoh's army (Ex 7-14) when he rescued his blessed descendants of Abraham from Egyptian captivity. For this, Moses praises him singing: 'The Lord is a warrior' (Ex 15:3)!

The Lord promised to give his people a land (Gn 17, Ex 13:11). Now when we read of Israel's pursuit of the possession of the Promised Land, we discover that it was God's unsavoury mandate that they should wage war on and wipe out its inhabitants:

See, the Lord your God has given you the land. Go up and take possession of it as the Lord, the God of your ancestors, told you... Begin to take possession of it and engage him in battle. (Dt 1:21, 2:24)

Over and over in Deuteronomy, we read that the Israelites 'took all his towns and completely destroyed them - men, women and children. We left no survivors' (Dt 2:34). Just when you might think that God might have disapproved at this point because of women and children being violently destroyed, you have to recall that it was God who said, 'Now begin to conquer and possess his land' (Dt 2:31). In fact, they are successful because, 'The Lord your God, who is going before you, will fight for you' (Dt 1:30). It is Yahweh who commands the Israelites to kill men, women and children (Davies 2010:90). It is God who guarantees that they do so because it is Yahweh the Warrior who goes before them in battle. But, later on in the text Yahweh accuses Israel of not destroying all the nations in Canaan. This is the contradictory dilemma of Yahweh both forbidding violence and yet using violence to carry out his purposes - which speaks to the incongruency and enigma on this theme. Considering that Yahweh is sovereign and has many ways, absent of just violence, in dealing with wayward humankind, why opt for violence, instead of causing more peaceful judgements.

\section{Yahweh's (un)prescriptive primacy of violence}

We saw earlier that the Lord's superintendence over human actions was for his good purposes (Gn 50: 20). We now have to pause and ask, 'what are/were His good purposes'? Thankfully we don't have to speculate because his good purposes are qualified in Genesis 50: 20 as '... what is now being done, the saving of many lives'. God has chosen to save many lives from the wrath that duly comes upon all humankind, as we saw in the flood, because of their corruption. Those many lives that he has chosen to save are those of Abraham and his descendants. All other human beings are subject to his righteous judgement. Thus, when he rains down sulphur and wipes the world out with a flood he is acting in righteous judgement. The same righteous 
judgement is meted out (controversially) by the use of human agents: Israel in war against Canaan's inhabitants. It is controversial because of the human agency with which he judges, but it is God righteously judging the wicked nonetheless just as he was with the flood and sulphur. But wasn't Israel commanded not to murder (Ex 20:13)? Extinguishing God's enemies by God's command is not listed as murder under Exodus 21 which expounds what constitutes murder. We cannot a priori determine how God should judge wickedness. He alone is God! The difference now is that through his judgement by means of Israel, he is superintending another arguable purpose as well: The securing of land for the people he has sovereignly chosen to save in accordance with his promise to them.

Thus, God's judgements (through flood, sulphur and war) are his divinely appointed acts of justice which do not prescribe a paradigm for humans to follow. This kind of Yahwistic enigma should be seen as Crossan (2015) declared,

A crime against both humanity and divinity to tell people so located that a military defeat is a punishment from God. This holds also, but for different reasons, on disease and drought, famine and even earthquake ... External invasions, internal famines, and other disasters were not divine punishments for how the people of Israel lived its covenantal life with God, but human consequences of where the nation of Israel lived it. (pp. 118-119)

\section{Yahweh's continuity and discontinuity of violence}

By the time we get to the New Testament, Abrahams' descendants are progressively revealed as all those who put their faith in Christ (Rm 4) (Van Aarde 2000:295). And Jerusalem, the Promised Land, is eschatologised by the writer to the Hebrews and shown to have been a foretaste of what was expected even by the Old Testament saints themselves:

\begin{abstract}
Abraham, when called to go to a place he would later receive as his inheritance, obeyed and went, even though he did not know where he was going. By faith he made his home in the Promised Land like a stranger in a foreign country; he lived in tents, as did Isaac and Jacob, who were heirs with him of the same promise. For he was looking forward to the city with foundations, whose architect and builder is God... they were longing for a better country - a heavenly one. Therefore, God is not ashamed to be called their God, for he has prepared a city for them. (Heb 11:8, 16)
\end{abstract}

From a Reformed perspective, it can be stated that God has made known that Abraham's descendants shall enter that city through faith in the powerful God the Warrior, who defeated the enemies that stand in the way of entering that City. The enemies of the true Promised Land are not flesh and blood that require military action. No, our war is 'against the rulers, against the authorities, against the powers of this dark world and against the spiritual forces of evil in the heavenly realm' (Eph. 6:12). Paul can't help but glee over Christ's victory when he writes, 'And having disarmed the powers and authorities, he made a public spectacle of them, triumphing over them by the cross' (Col. 2:15).

Christians, as Abraham's descendants, have victory over the enemies that stand between them and the Promised Land through Christ's triumph at the cross. They therefore do not take up arms as Israel did but the armour of God that we adorn is a steadfast shield of faith in the victorious Warrior God and the Word of God as the sword by our side (Eph 6:14-17). The spiritual warfare in which they are engaged then gives Christians a whole new perspective on the things of this world.

We have to bear in mind that because of Jesus' historical victory on the cross of Calvary, 'there is an "already" aspect of the kingdom, and a "not yet" aspect: the kingdom has already come, but it has not yet arrived' (Carson 1999:15). Christians thus are in the world, but are not of it (Jn 17:14, 16). We are commanded to live in this world by the ethical principles of another.

\section{A religious response to violence (or not)?}

The refrain 'You have that it was said... But I tell you' is repeated at least six times throughout the Sermon on the Mount (without counting the times when it is inferred but not explicitly said). It thus firmly anchors the Sermon on the Mount in the Old Testament. Rather than indicating Jesus' changing of the law, which he painstakingly denies (Chr 5:17-18), the refrain actually serves to show that Jesus is going beyond the letter of the law and revealing its spirit. Thereby, Jesus was indicting the Jewish crowds to whom he was preaching for breaking God's law by displaying only a veneer of observance of it (and adding faulty traditions to it). I am confident of this because in Matthew 4:17 Jesus was preaching 'Repent, for the kingdom of God has come near' (Nolland 2005:1135).

So in the same way that the saying, 'I tell you that anyone who looks at a woman lustfully has already committed adultery with her in his heart' (Mt 5:28) would have been a paradigm shifting indictment; the Beatitudes also carry the same surprise punch. In the first analysis then, it is worthy to consider that when Jesus was 'preaching the good news of the kingdom' (Mt 4:23), given the violent history of Israel (Pietersen 2021:235) we've necessarily discussed in some detail, he had to shift the Jewish paradigm with regard to the fitting disposition of those to whom the promised kingdom belongs. N.T. Wright (1993) helpfully portrayed the historical state of the Jewish crowds that Jesus is speaking into, while Carson (1999) showed how the text paints the personal condition of people today that Jesus counts worthy of God's kingdom in light of God's revelation climaxing in Christ. What is of significance for this article is the discounting of the legitimacy of violence in the attitude of the believer (inferably, since Christ's victorious triumph over the enemies of the kingdom). Reflecting on Matthew 5, Hays (1996:322) is also 
convinced that the teaching of the kingdom of God comes as a surprise. $^{2}$

Israel 'is ready to work and struggle and fight to bring it in. But the people to whom it belongs are the poor in spirit'. (Wright 1993:289). Poverty characterised the oppression Israel was under because of its subjection to foreign rule. But instead of the courage of spirit to fight, that they would have thought was appropriate because they had an inherent right to the kingdom, Israelis needed the opposite attitude because they, like everyone else, actually never had a right to the kingdom. God is gracious in giving the kingdom through the victory of Christ's warfare on the cross (therefore, physical violence is in vain at the last). All humankind are sinners and deserve to be under an everlasting tyrannical reign of oppression. They must own their condition, deeply. They must acknowledge that in spiritually (in the deepest sense of reality), they are 'bankrupt' (Stott 1988:39), and therefore must confess that they are 'unworthy before God' (Carson 1999:18). Such is the disposition of the inheritors of the kingdom of God for whom Christ has triumphed (Wright 1993):

Israel longs for consolation for paraklesis. But YHWH has in mind to give her, not the consolation of a national revival, in which her old wounds will be healed by not inflicting wounds on others, but the consolation awaiting those who are in genuine grief. (p. 289)

It is a rebellion against God that prevented Israel from entering the kingdom in the Old Testament shadow of the true kingdom (Heb 3:17-19) that rebellion is ever present and shall be mourned until the return of Christ.

'Israel desires to inherit the earth; she must do it Jesus' way, by meekness' (Wright 2012:289). The inheritance of the earth comes to those who advance the interest of another ahead of their own. The meekest man ever before Jesus demonstrated his meekness chiefly and shied away from violence 'by his controlled self-commitment to the Lord when his person and privilege were under attack' (Carson 1999:21). Ultimately, it is the Lord Jesus who supremely displays by making himself the object of severest violence for the sake of others (Carson 1999:21).

Israel thirsts for justice; but the justice she is offered does not come by way of battles against physical enemies. It is not the way of anger, of a 'justice' which really means 'vengeance'. It is the way of humility and gentleness. (Wright 2012:289)

The Greek word translated as righteousness in most English Bibles is the same root word as for justice, which Wright favours. Again, we have to see the indictment on Jewish society here, which Wright points out, and not just the exhortation. Justice is not to be pursued through violence by God's people. Meekness and mercy, which sandwich this verse, clearly unpack the character of the just or the righteous contextually. This is the 'conformity to God's will' (Carson 1999:23) which believers ought to hunger and thirst for. Not violence.
Israel longs for mercy, not least the eschatological mercy of final rescue from her enemies. But mercy is reserved for the merciful, not the vengeful. (Wright 1999:289)

Israel longs for the vision of her god; but this is the prerogative not of those who impose an external purity, but of those with purity heart. (Fletcher-Louis 2007:58)

Again, purity of heart is sandwiched by 'mercy' and 'peacemaking', thus indicating its content. Israel desires to be called the creator's son, being vindicated by him in the dramatic historical proof of national victory. But those whom Israel's God will vindicate as his sons will be those who copy their father; and that means peacemakers' (Wright 1999:289). Violence is the antithesis of peace. God's crushing of His Son was ultimately to make peace. This is what His followers ought to imitate. Persecution will be inevitable for people who follow this way, Jesus' way, but those who are persecuted because they follow this way are indeed assured of great vindication (Wright 1999:289).

In Africa, Christianity has, for the most part, been entangled with violence to such a degree that colonialism, as Moyo (2010:1) reported, 'depicted Christianity as expressly part of the colonial machinery'. Kenyan scholar Ali Mazrui (1967) surmised:

Just as Augustine had allied Christianity with a concept of Pax Romana, so did Christianity later come to be linked to the whole vision of Pax Britannica. In Africa, Christianity came to be particularly associated with colonization. (p. 198)

African Christians, on the other hand, who struggled for liberation from European oppression were not averse to applying the Beatitudes to encourage their people in response to the violent European colonialists who claimed the name of Christianity in their actions. The Ghanaian party Convention People's Party (CPP) proclaimed in exhortation (Mt 5:3-12), 'Blessed are they who are imprisoned for selfgovernment's sake; For theirs is the freedom of this land' (Moyo 2010:6). ${ }^{3}$

Augustine understood verses 38-48 of Matthew 5 as 'literally forbidding self-defense, but they do not preclude fighting in defense of an innocent party' (Hays 1996:320), and others have given interpretations that run away from the plain meaning of renouncing violent, retributive actions. Turning the other cheek, as Hays (1996:323) argued, is Jesus emphatically commanding Christians to renounce violence that 'even' in self-defense they ought not retaliate! 'Where the Torah restricts retaliation, Jesus forbids it altogether' (Hays 1996:325). Stott (1988:104) was more exegetically sound when he argued that the Old Testament passage alluded to in ch 5:38-48 is Exodus 21. Therefore, the indictment of Jesus' words is that Pharisees misappropriated legislation (designed to be merciful in judicial retribution) to personal relationships 'as an excuse for the very thing it was instituted to abolish,

3 whether this is a fitting application of the Beatitudes................................. is to portray the inony in history; that European professing Chistians were happy to use violence to advance their mission while the persecuted African professing Christians appealed to the same Bible as the Europeans, to show that the Bible was in favour of the nonviolence. 
namely personal vengeance'. Furthermore, Matthew 26:51-52 shows that even in defence of a third party, violence ought not be resorted to (Hays 1996:324).

At the least then, in the Sermon we observe Israel (the people of God, Abraham's descendants, the Church) being exhorted here by Jesus to embody attitudes that stand diametrically opposed to violent action and embrace the lifestyle of the kingdom she is a part of that has been secured for her by Christ. Christians ought to live as though they belong to a different world because they do; following the paradigmatic life of Christ our Lord (Weaver 2018:2). And for this reason, they ought to renounce violence. Such teaching was utterly paradigm shifting and amazing for the crowd that gathered (Mt 7:28-29).

\section{Breaking violent and dramatic traditions}

When we survey the Synoptics at large, we find similar exhortations sprinkled across them, for example, Luke 6 demonstrates non-retaliation, meekness and suffering; Mathew 18 - mercy. Mark $8 \mathrm{ff}$. is nothing less than a promise of persecution for the follower of Christ and the exhortation for him or her to endure. Jesus does not retaliate, but prays for the enemies who crucify Him (Lk 23:34). The Gospels therefore show that a believer ought to have a propensity for peace and endure under suffering (Van Aarde 2000:253-254).

When Jesus is tempted to turn his back on the cup of suffering, he was about to drink, Yoder suggests that that temptation was the 'temptation to resort to armed resistance' (Hays 1996:322). Hays then supported this claim by the fact that Jesus told his disciple to put his sword away before saying, 'all who take the sword will perish by the sword'. We have to qualify this though by the fact that Jesus would not have thought salvation would have come by military power, however persuasive this interpretation of his temptation is. I think it is more precise to say that his temptation was to save his life. The means to escape Roman captivity therefore are secondary and are plausibly violent. Gerstenberger (2002) posited:

After the last vain rebellions against the power of the Roman state (70 and $135 \mathrm{CE}$ ), Judaism did not again become a state religion, but remained limited to school and community theology. (...) It has also been spared the formation of exclusivist dogmas. There have been neither crusades, nor inquisitions nor the burning of witches in the Jewish communities. (...) By contrast, in Christianity the problems piled up as a consequence of the formation of large societies, the growth of the state, an increase in the power of the churches and the unscrupulous exploitation of the power which had accrued to it to an excessive degree. (p. 82)

Of Mark 11:15-19 Hays (1996:334) persuasively insisted, given the context, that the 'violent' cleansing of the temple ought not to be seen as a paradigmatic warrant of violence for Christians but as 'prophetic symbolism' demonstrating the destruction of the temple. Strijdom (2016) also agreed that:
The prophetic tradition, for all its courageous insistence on God's distributive justice, often against the abuses of royal power, also consistently in a Deuteronomic vein threatened Israel with God's violent retribution for failing to adhere to the distributive demands of the covenant. (p. 4)

I think this understanding is exegetically and biblicaltheologically sound. However, it still does not resolve the Yahwistic enigma moving beyond the human mind.

Barth saw the Old Testament commands to war as an indication of the possibility for God to command Christians to go to war again at some point (Hays 1996:336). I think he has failed to recognise that, biblical-theologically, Old Testament war found fulfilment at the cross of Christ. Likewise, as Hoekema (1986:917) noted, reformed churches are reputed as 'war churches' who view pacifism as 'naive optimism'. Hoekema (1986:918) recorded that the just-war tradition, rooted in the ethical theories of Plato and Cicero and formulated within the Christian tradition by Augustine, Aquinas and the Protestant Reformers, 'defends military force as a last resort against grave injustice'. Important to note here is that military force is a last resort for just-war defenders who espouse the same concerns for peace and harmony that pacifists cherish. The difference is that pacifists preclude war as an option under any circumstance which does not mean that they are passive with regard to settling disputes nor does it mean that pacifism is basically 'based on optimistic humanism' (Hoekema 1986:918-919). I think pacifists have a better exegetical and biblical-theological leg to stand on here. Hoekema (1986:919) also refuted the objection, subscribed to by Grudem on the basis of Romans 13 (Grudem 2010:391), that pacifism does not make a distinction between Christians as individuals and the State. He reasoned that 'Jesus Christ is the Lord not just of the church, nor of a special sphere of religious activity, but of all the natural and human world' (Northcott 1999:377). Pacifism as such dates back to the early church as so dominant a view, that the church fathers who are usually on different ends of the spectrum on most things are united with regard to the use of armed force (Hoekema 1986:918).

\section{Conclusion}

To take a closer look at violence and Yahweh's congruency with violence in history and the present world, I cannot but agree with Hays (1996:336) when he asserted that Christians who suffer and endure violence on earth will be vindicated at the eschaton. I think he is right based on the support he finds in 1 Thessalonians 1; this is where despite intense persecution, Paul encourages them to show victory over evil by imitating Jesus' non-violent and patient endurance. They are not to seek vengeance here and now. Vengeance is of the Lord and $\mathrm{He}$ will vindicate his people. This is the perspective given by the prospect of 'New Creation'. From the perspective of 'community' (Kuligin 2006:145), the New Testament encourages the Church to exhibit peace, reconciliation and endurance under suffering with the 'cross' as our paradigm (Hays 1996:337). Yoder agreed emphatically that Jesus is our example 'in his cross' (Yoder 1972:97). Thus, asking Christians to renounce violence while passionately pursuing justice with 
the comfort that the Lord will vindicate them at the last is good and right. However, while Yahweh seems to be 'seemingly silent' in modern day violence (Pietersen 2021:234-235), the historical biblical accounts of Yahweh's firm voice is no different, but it does not encourage the followers of Yahweh to take up arms and fight in-order to vindicate Yahweh or themselves.

\section{Acknowledgements Competing interests}

The author declares that he has no financial or personal relationships that may have inappropriately influenced him in writing this article.

\section{Author's contributions}

D.P. is the sole author of this research article.

\section{Ethical considerations}

This article followed all ethical standards for research without direct contact with human or animal subjects.

\section{Funding information}

This research received no specific grant from any funding agency in the public, commercial or not-for-profit sectors.

\section{Data availability}

Data sharing is not applicable to this article as no new data were created or analysed in this study.

\section{Disclaimer}

The views and opinions expressed in this article are those of the author and do not necessarily reflect the official policy or position of any affiliated agency of the author.

\section{References}

Carson, D.A., 1999, Jesus' Sermon on the Mount, Baker Books, Grand Rapids, MI.

Chidester, D., 2012, Wild religion: Tracking the sacred in South Africa, University of California Press, Berkeley, CA.

Collins, J.J., 2005, The Bible after Babel: Historical criticism in a postmodern age, Eerdmans, Grand Rapids, MI.

Crossan, J., 2015, How to read the Bible and still be a Christian: Struggling with divine violence from Genesis through Revelation, Harper Collins, New York, NY.

Davies, E.W., 2010, The immoral Bible: Approaches to Biblical Ethics, T\&T Clark, London.

Fletcher-Louis, C., 2007, 'Jesus as the high priestly messiah: Part 2', Journal for the Study of the Historical Jesus 5(1), 57-79.

Gerstenberger, E.S., 2002, Theologies in the Old Testament, T\&T Clark, London.

Grudem, W., 2010, Politics according to the Bible, Zondervan, Grand Rapids, MI.

Hays, R.B., 1996, The moral vision of the New Testament, Harper Collins, New York, NY. Hoekema, D.A., 1986, A practical Christian pacifism, Christian Century, Chicago, IL.

Horsley, R.A., 2003, Jesus and Empire: The Kingdom of God and the new world disorder, Fortress, Minneapolis, MN

Huber, W., 2011, 'Religion and violence in a globalised world', Verbum et Ecclesia 32(2), Art. \#581, 8 pages. http://dx.doi.org/10.4102/ve32i2.581

Kuligin, V., 2006, Ten things I wish Jesus never said, Crossway Books, Wheaton, IL.

Mazrui, A.A., 1967, Towards a Pax Africana: A study of ideology and ambition, Weidenfeld \& Nicolson, London.

Moyo, F., 2010, The Bible, the bullet and the ballot, Pickwick Publications, Cape Town.

Nolland, J., 2005, The Gospel of Matthew: A commentary on the Greek text, Eerdmans, Grand Rapids, MI.

Northcott, M.S., 1999, 'The environment and Christian ethics', Pro Ecclesia 8(3), 375-377.

Pietersen, C.D., 2021, "Disempowerment of and violence against women: Old Testament perspectives", Unpublished thesis, University of Pretoria.

Stott, J., 1988, The message of the Sermon on the Mount, IVP, Leicester.

Strijdom, J., 2016, 'Violence in the Christian Bible: Assessing Crossan's use of "violence" as a key analytical concept', HTS Teologiese Studies/Theological Studies 72(4), a3445. https://doi.org/10.4102/hts.v72i4.3445

Van Aarde, A.G., 2000, "Historicization of myth: the metaphor "Jesus - child of god" and its Hellenistic Semitic and Greco-Roman background", Published Thesis, University of Pretoria, Pretoria.

Weaver, D.J., 2018, 'Suffering violence' and the kingdom of heaven (Mt 11:12): A Matthean manual for life in a time of war', HTS Teologiese Studies/ Theological Studies 67(1), Art. \#1011, 12 pages. https://doi.org/10.4102/hts. v67i1.1011

World Health Organization, 2021, Violence against women, viewed 03 January 2021 from https://www. who.int/health-topics/violence-against-women\#tab=tab_1.

Wright, N.T., 1993, Jesus and the victory of God, Fortress Press, Minneapolis, MN.

Wright, N.T., 2012, Jesus and the victory of God, SPCK, London.

Yoder, J.H., 1972, The politics of Jesus, Eerdmans, Grand Rapids, MI. 